\title{
Rapid inhibition of ongoing DNA synthesis in human glioma tissue by genistein
}

\author{
JUAN SEBASTIAN YAKISICH ${ }^{1}$, INGRID OHLSSON LINDBLOM $^{2}, \AA^{\text {AKE SIDEN }}{ }^{1}$ and MABEL H. CRUZ ${ }^{1}$ \\ ${ }^{1}$ Division of Neurology, Department of Clinical Neuroscience, Karolinska University Hospital Huddinge; \\ ${ }^{2}$ Department of Neurosurgery, Karolinska Hospital, Karolinska Institute, Stockholm, Sweden
}

Received February 6, 2009; Accepted May 1, 2009

DOI: $10.3892 /$ or_00000473

\begin{abstract}
The effect of genistein, a protein tyrosine kinase and topoisomerase II inhibitor, on the DNA synthesis rate was studied in 21 human glioma specimens obtained at routine craniotomies for tumor resection. Ongoing DNA synthesis rate was determined by using a method based on the generation of tissue mini-units immediately after tumor resection and short incubation time (0-120 min) with [methyl- ${ }^{3} \mathrm{H}$ ]-thymidine. A $9-77 \%$ inhibition of DNA synthesis rate by $100 \mu \mathrm{M}$ genistein was observed in $18 / 21$ of the glioma specimens. In these cases, the average percentage of inhibition was $55 \pm 20 \%$ (mean \pm SD, $\mathrm{P}<0.0001$, Student's t-test) and the inhibitory effect was $>50 \%$ in $12 / 18$ of the cases. In 3 cases genistein increased the DNA synthesis rate. The inhibitory effect of genistein had a short-time onset and was concentration-dependent. Additional experiments in 4 cases showed that herbimycin A had no effect on DNA synthesis rate while etoposide inhibited similarly to that of genistein. Our results suggest that the effect of genistein on DNA synthesis rate in gliomas is independent of protein kinase inhibition and probably mediated by topoisomerase II inhibition. In the RG2 model, $50 \mu \mathrm{M}$ genistein inhibited ongoing DNA synthesis in glioma cells with little or no effect in normal tissue. The data also encourage further investigations on the therapeutic potential of genistein for gliomas.
\end{abstract}

\section{Introduction}

The uncontrolled growth of gliomas may result in part from excessive activation of protein tyrosine kinases. Consistent with this hypothesis, protein tyrosine kinase inhibitors reduce

Correspondence to: Dr Juan Sebastian Yakisich, Division of Neurology, Department of Clinical Neuroscience, Karolinska University Hospital Huddinge, Karolinska Institute, Stockholm, Sweden

E-mail: sebastian.yakisich@ki.se or yakisich@gmail.com

Key words: brain tumors, gliomas, DNA synthesis, cell proliferation, genistein, RG2 model the proliferation of human glioma cell lines with $\mathrm{IC}_{50}$ proliferation values approximating those for inhibition of tyrosine kinase activity in cell free protein extracts (1) and block infiltration of glioblastoma spheroid cells into normal tissue in vitro by a mechanism involving inhibition of epidermal growth factor receptor (EGF-R) associated tyrosine kinase (2). The c-erbB gene encoding EGF-R is amplified and overexpressed in up to $50 \%$ of malignant gliomas (3). Tyrosine kinase activation of the EGF-R leads to phosphorylation of intracellular proteins, thus initiating an intracellular cascade that leads to cell division.

The isoflavone genistein is found in high amount in soy and has been shown to inhibit the growth of several normal and neoplastic cell lines (4) including human glioma cell lines $(1,5)$. The inhibitory effect on cell proliferation (DNA synthesis) rate is generally attributed to inhibition of tyrosine kinases, especially the EGF-R associated tyrosine kinase activity, topoisomerase II (6) and histidine kinase activity (7) as well as other effects (8). Compared to etoposide (another topoisomerase II poison), the cytotoxic and genotoxic effects of genistein differ significantly (9). Genistein is a small molecule (M.W. 270.2 Da). When injected intraperitoneally to rats, it rapidily appears in brain tissue and in microdialysate fluid from the corpus striatum indicating that genistein is capable of crossing the blood-brain barrier (10).

These data suggest that genistein and other protein tyrosine kinase inhibitors might have a therapeutic potential for tumors expressing high levels of tyrosine kinase activities. In a previous study, we found a strong inhibitory effect of genistein on ongoing DNA synthesis rate in the developing rat cerebral cortex and a much weaker inhibitory effect in adult rat cerebral cortex (11). Although ongoing DNA synthesis is one of the less studied targets for antineoplastic therapy, it might constitute a useful target to treat highly proliferative cancers, specially those arising in low proliferating tissues. In theory, the main advantage of ongoing DNA synthesis inhibitors is their ability to inhibit DNA replication within short period of time. Thus, higher concentrations of drugs might be able to be delivered locally into fast growing tumors with tolerable toxicity to the surrounding normal low proliferative normal tissue.

We studied the effect of relatively high concentrations of genistein on ongoing DNA synthesis rate in mini-units prepared from human gliomas as well as in mini-units prepared from the rat RG2 glioma model. 
Table I. Clinical data of the 25 patients included in the study as well as protein content per microwell, spontaneous DNA synthesis rate and effect of $100 \mu \mathrm{M}$ genistein.

\begin{tabular}{|c|c|c|c|c|}
\hline $\begin{array}{l}\text { Patient no. } \\
\text { age/gender }\end{array}$ & Histopathology & $\begin{array}{l}\text { Previous } \\
\text { treatment }^{\mathrm{a}}\end{array}$ & $\begin{array}{l}\text { Spontaneous DNA synthesis } \\
\text { rate }(\mathrm{cpm} / \mathrm{mg} \text { of protein })^{\mathrm{d}}\end{array}$ & $\begin{array}{c}\text { Change }(\%) \text { of DNA synthesis } \\
\text { rate by } 100 \mu \mathrm{M} \text { genistein }{ }^{\mathrm{d}, \mathrm{f}}\end{array}$ \\
\hline $140 / \mathrm{M}$ & GB & None & $140(4)$ & $\mathrm{ND}^{\mathrm{e}}$ \\
\hline $255 / \mathrm{F}$ & ODG & None & $153(3)$ & $\mathrm{ND}^{\mathrm{e}}$ \\
\hline $365 / \mathrm{M}$ & GB & None & $104(2)$ & $\mathrm{ND}^{\mathrm{e}}$ \\
\hline $465 / \mathrm{M}$ & GB & Surgery + Rx $+\mathrm{CCNU}^{\mathrm{c}}$ & $742(4)$ & $\mathrm{ND}^{\mathrm{e}}$ \\
\hline $565 / F$ & GB & None & $204(3)$ & $-74(3)$ \\
\hline $657 / \mathrm{F}$ & GB & None & $176(3)$ & $-74(3)$ \\
\hline $763 / \mathrm{M}$ & GB & None & $776(2)$ & $-68(3)$ \\
\hline $858 / \mathrm{M}$ & AA & None & $196(2)$ & $-66(2)$ \\
\hline $944 / F$ & AA & $\mathrm{Rx}+\mathrm{CCNU} ; \mathrm{CCNU}^{\mathrm{c}}$ & $15(1)$ & $-57(1)$ \\
\hline $1053 / \mathrm{M}$ & AA & Surgery + Rx + CCNU & $55(2)$ & $-44(1)$ \\
\hline $1145 / \mathrm{M}$ & GB & Surgery $+\mathrm{Rx}+\mathrm{CCNU}^{\mathrm{c}}$ & $137(2)$ & $-59(2)$ \\
\hline 12 63/M & GB & None & $22(2)$ & $-54(2)$ \\
\hline 13 64/M & $\mathrm{GB}^{\mathrm{b}}$ & None & $5(2)$ & $+64(2)$ \\
\hline 14 66/F & A ODG & None & $79(2)$ & $-34(3)$ \\
\hline 15 43/M & GB & None & $124(4)$ & $-73(4)$ \\
\hline 16 48/M & A ODG & Surgery $+\mathrm{CCNU}^{\mathrm{c}}$ & $284(3)$ & $-44(3)$ \\
\hline $1752 / \mathrm{F}$ & GB & Surgery + Rx + CCNU & $234(3)$ & $-70(4)$ \\
\hline 18 23/F & PA & None & $21(3)$ & $-27(2)$ \\
\hline 19 35/M & $\mathrm{AA}$ & None & $57(4)$ & $-77(4)$ \\
\hline $2042 / \mathrm{M}$ & $\mathrm{OA}$ & None & $10(4)$ & $-25(4)$ \\
\hline $2140 / \mathrm{F}$ & GB & Surgery + Rx + CCNU & $9(2)$ & $-64(2)$ \\
\hline $2231 / \mathrm{M}$ & $\mathrm{GB}^{\mathrm{d}}$ & $\mathrm{Rx}^{\mathrm{c}}$ & $10(4)$ & $+18(3)$ \\
\hline $2355 / \mathrm{M}$ & GB & None & $221(4)$ & $-64(4)$ \\
\hline $2465 / F$ & GB & None & $3(4)$ & $+79(4)$ \\
\hline $2562 / F$ & GB & None & $5(3)$ & $-9(4)$ \\
\hline
\end{tabular}

${ }^{\mathrm{a}} \mathrm{GB}$, glioblastoma; ODG, oligodendroglioma; AA, anaplastic astrocytoma; A ODG, anaplastic oligodendroglioma; PA, pilocytic

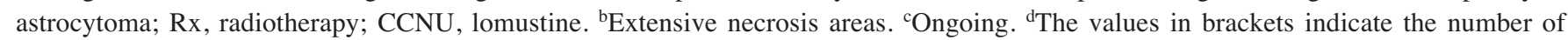
determinations. ${ }^{e} \mathrm{ND}$, not determined (specimens used only for studying the temporal incorporation of the radioactive precursor); ${ }_{-}^{\mathrm{f}}$, inhibition; + , stimulation.

\section{Materials and methods}

All studies were approved by the Ethics Committee at Huddinge University Hospital. Tumoral tissue specimens were obtained at routine craniotomies for tumor resection. Genistein (Costa Mesa, CA, USA) was prepared as stock solution $(100 \mathrm{mM})$ in dimethylsufoxid (DMSO, Sigma, Sweden) and stored at $-20^{\circ} \mathrm{C}(12)$. The final dilutions (10$100 \mu \mathrm{M})$ were done in Dulbecco's modified Eagle's medium with glutamine and 4,500 mg/l D-glucose (DMEM; Gibco/ Life Technologies, Sweden) keeping DMSO concentration below $0.1 \%(\mathrm{v} / \mathrm{v})$. DMSO alone at the same concentration was used as control.

Generation of tissue mini-units, determination of [methyl$\left.{ }^{3} \mathrm{H}\right]$-thymidine incorporation into DNA and ongoing DNA synthesis rate, protein quantitation and determination of effect of genistein were performed as previously reported $(11,13)$. Briefly, mini-units of glioma tissue were generated immediately after tumor resection. These mini-units were then incubated in microwell plates (Nunc, Denmark) with DMEM containing $2 \mu \mathrm{Ci} / \mathrm{ml}\left[\right.$ methyl- $\left.{ }^{3} \mathrm{H}\right]$-thymidine (Amershan, UK) and genistein or DMSO. Each experimental point was in all but 2 cases determined by at least duplicate. The DNA synthesis rate was calculated as cpm/mg of protein/ min. The effect of genistein was determined as change (\%) of DNA synthesis rate compared to the corresponding control (Table I) or percentage of control DNA synthesis rate (Fig. 2-4).

Glioma model. The RG2 rat glioma model was performed as previously described (14).

\section{Results}

Effect of genistein on ongoing DNA synthesis in tissue miniunits prepared from human gliomas. As shown in Table I, 


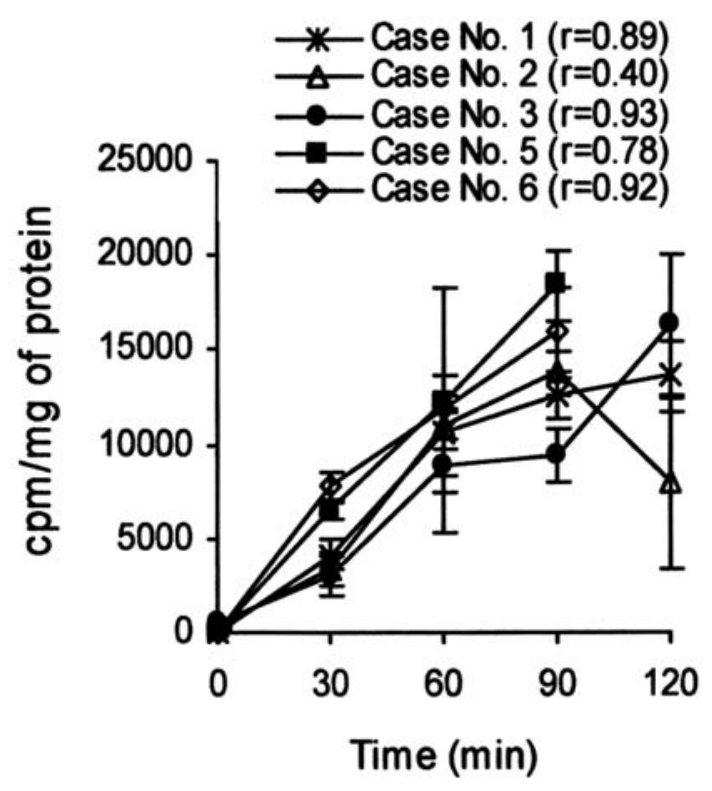

- Case No. $4(r=0.92)$

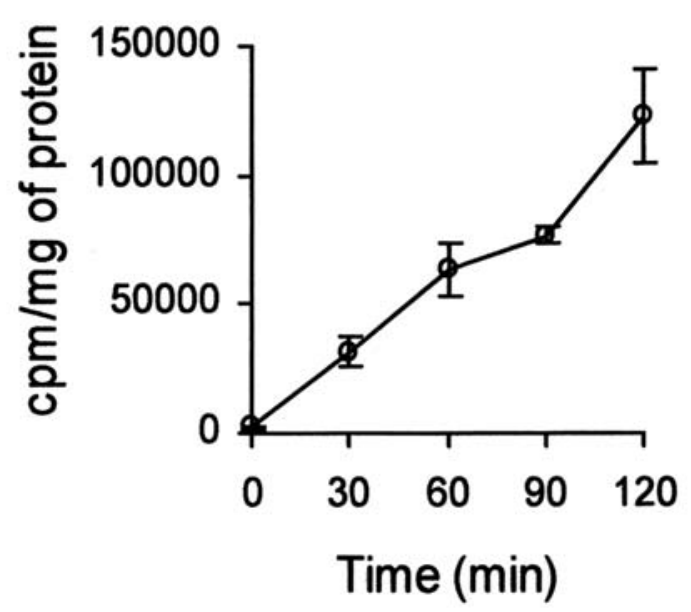

Figure 1. Temporal incorporation of $\left[\right.$ methyl- $\left.{ }^{3} \mathrm{H}\right]$-thymidine into DNA in mini-units from 6 different tumor specimens. Each point is the mean \pm SEM of triplicates except for 0,30 and $60 \mathrm{~min}$ of case no. 5 and 6 (duplicates). $\mathrm{r}=$ correlation coefficient.

tissue specimens were obtained from 15 males and 10 females with an age range of 23-66 years. The histopathological diagnoses were: glioblastoma (16 cases), anaplastic astrocytoma (4 cases), anaplastic oligodendroglioma (2 cases) and one case each of oligodendroglioma, oligoastrocytoma, and pilocytic astrocytoma. The interval between symptomatic onset and present surgery ranged from $<1$ month to $>5$ years. Previous or ongoing treatment was present in 8 patients.

Tissue mini-units generated from 6 different tumor specimens were incubated in DMEM containing $2 \mu \mathrm{Ci} / \mathrm{ml}$ [methyl- ${ }^{3} \mathrm{H}$ ]-thymidine during $0,30,60,90$ and $120 \mathrm{~min}$ (cases no. 1-4) and during 0, 30, 60 and 90 min (case no. 5 and 6). A quite linear incorporation of the radioactive precursor into DNA over time was observed up to 90 min despite the large intertumoral differences in the net rate of [methyl $\left.{ }^{3} \mathrm{H}\right]-$ thymidine incorporation (Fig. 1).

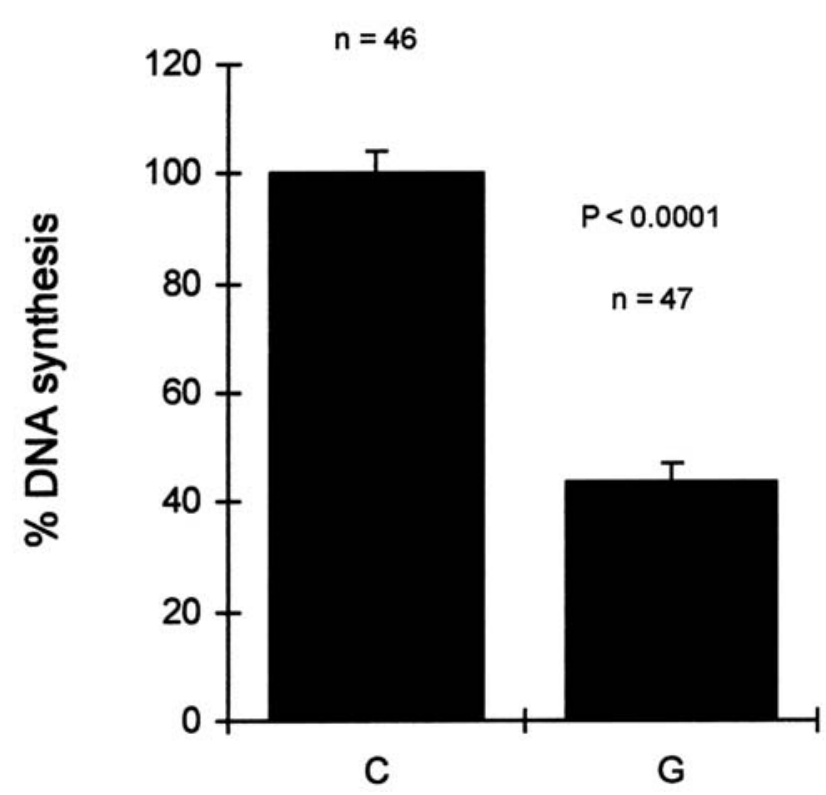

Figure 2. Effect of $100 \mu \mathrm{M}$ genistein $(\mathrm{G})$ on ongoing DNA synthesis in mini-units prepared from human gliomas. DMSO at equivalent concentration was used as control (C). Data are the mean \pm SE of 46/47 (n) determinations from mini-units prepared from cases 5-16 (see Table I for details).

Tissue mini-units generated from tumor specimens were incubated in DMEM containing $2 \mu \mathrm{Ci} / \mathrm{ml}$ [methyl $\left.{ }^{3} \mathrm{H}\right]-$ thymidine plus DMSO alone (cases no. 1-25, controls/spontaneous DNA synthesis rate) or $100 \mu \mathrm{M}$ genistein (cases no. 5-25) for $90 \mathrm{~min}$. This concentration of genistein was chosen since it has been shown to inhibit cell proliferation (DNA synthesis) rate in different tissues $(1,11,12)$. The standard incubation time of 90 min was chosen since this time gives a suitable difference in radioactive precursor incorporation between control and experimental samples. Furthermore, this short incubation time ensures minimal metabolic changes and allows monitoring of ongoing DNA synthesis rate $(11,13,15)$. A high (around 250-fold) interspecimen variation of spontaneous DNA synthesis rate was observed (Table I). Genistein at $100 \mu \mathrm{M}$ decreased the DNA synthesis rate in $18 / 21$ of the specimens. The percentage of inhibition was $9-77 \%$ and was $>50 \%$ in $12 / 18$ of these cases. In the remaining 3 cases (13, 22 and 24) genistein increased the DNA synthesis rate. In the 18 cases where genistein decreased the DNA synthesis rate, the average percentage of inhibition was $55 \pm 20 \%$ (mean \pm $\mathrm{SD}, \mathrm{P}<0.0001$, Student's t-test) (Fig. 2). The inhibitory effect of genistein was $>50 \%$ in $8 / 9$ cases with spontaneous DNA synthesis rates $>100 \mathrm{cpm} / \mathrm{mg}$ of protein/min while this was found for only $4 / 12$ cases with spontaneous DNA synthesis rates $<100 \mathrm{cpm} / \mathrm{mg}$ of protein/min (Table I). However, the quite heterogeneous and limited material does not allow any conclusion regarding possible relations between DNA synthesis rate and effect of genistein.

The concentration-dependent and temporal effects of genistein could, due to the limited amount of tumor tissue, only be studied in a few cases. Tissue mini-units generated from one tumor specimen (case no. 19) were also incubated with DMEM containing $2 \mu \mathrm{Ci} / \mathrm{ml}$ [methyl- ${ }^{3} \mathrm{H}$ ]-thymidine plus DMSO alone or 10,50 and $100 \mu \mathrm{M}$ genistein for $90 \mathrm{~min}$. The results showed that genistein had a concentration-dependent 


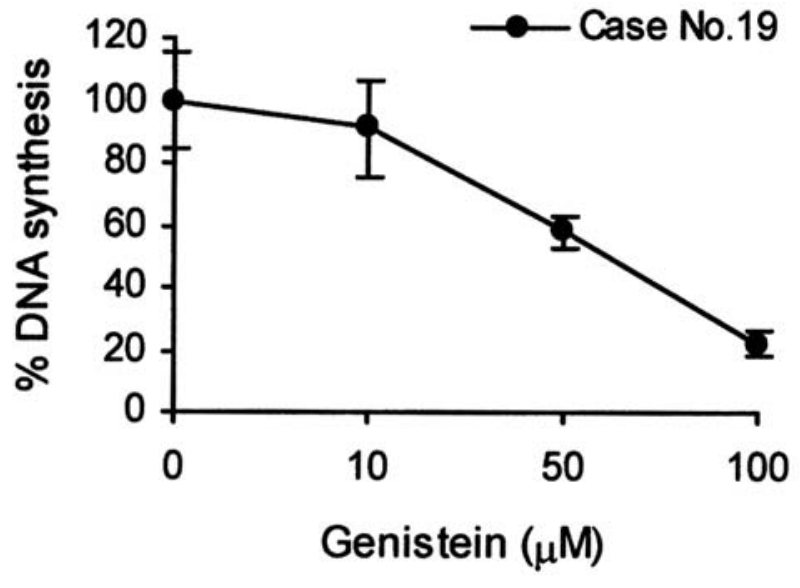

Figure 3. Concentration-dependent effect of genistein on DNA synthesis rate in mini-units prepared from one tumor specimen. Data are the mean \pm SEM of one experiment performed in quadruplicate. No significant inhibition was detected in control mini-units treated with equivalent concentrations of vehicle $[0.1 \%(\mathrm{v} / \mathrm{v}) \mathrm{DMSO}]$.

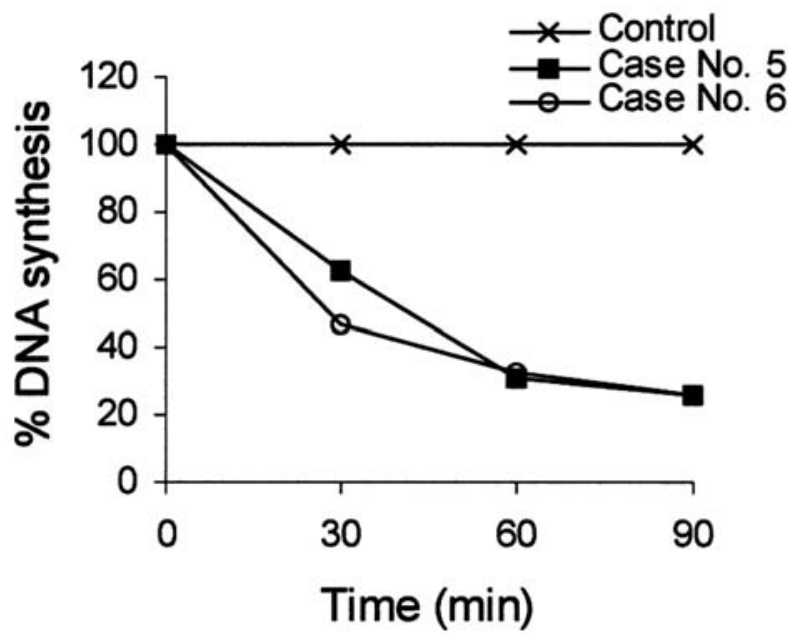

Figure 4. Temporal effect of $100 \mu \mathrm{M}$ genistein on DNA synthesis rate in mini-units prepared from 2 different tumor specimens. Each point is the mean \pm SEM of duplicates $(0,30$ and $60 \mathrm{~min})$ or triplicates $(90 \mathrm{~min})$. Control mini-units were treated with $0.1 \%(\mathrm{v} / \mathrm{v})$ DMSO.

effect on DNA synthesis rate (Fig. 3). Tissue mini-units generated from 2 tumor specimens (case no. 5 and 6) were incubated with DMEM containing $2 \mu \mathrm{Ci} / \mathrm{ml}\left[\right.$ methyl $\left.{ }^{3} \mathrm{H}\right]$-thymidine plus DMSO alone (controls) or $100 \mu \mathrm{M}$ genistein for 0,30 , 60 and $90 \mathrm{~min}$. The results showed that genistein decreased the DNA synthesis rate within 30 min (Fig. 4). Finally, in 4 cases (no. 10, 19, 21 and 23), the experiments included exposure to $10 \mu \mathrm{M}$ herbimycin A [a potent tyrosine kinase inhibitor (16)] and/or $250 \mu \mathrm{M}$ etoposide [a selective inhibitor of topoisomerase II (6)]. Herbimycin A had no effect on DNA synthesis rate while etoposide inhibited the DNA synthesis rate to a similar extent as genistein (data not shown).

Effect of genistein on ongoing DNA synthesis in tissue miniunits prepared from the RG2 rat glioma model. The tissue mini-units were prepared from tumor specimens obtained from the rat RG2 glioma model and incubated for $90 \mathrm{~min}$ in DMEM

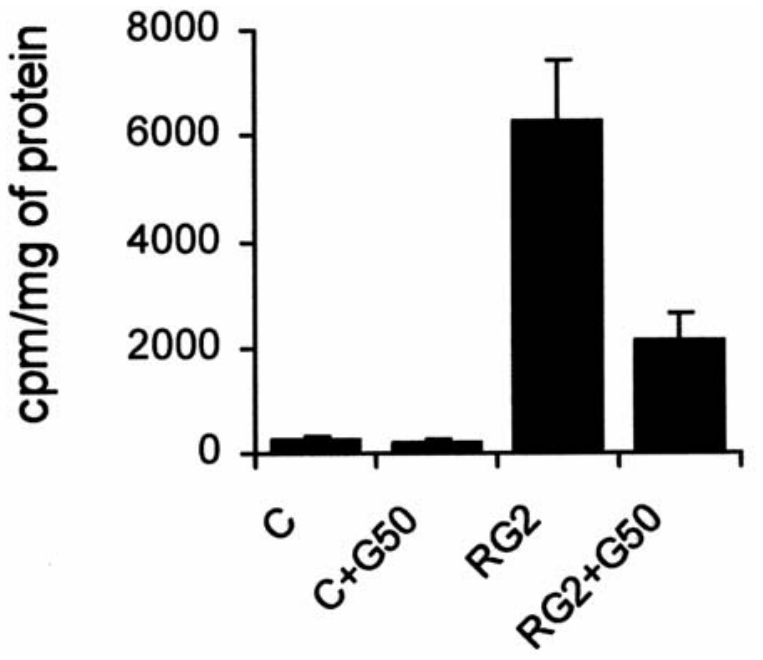

Figure 5. Effect of genistein on ongoing DNA synthesis in tissue mini-units prepared from the RG2 rat glioma model. The mini-units prepared from normal tissue $(\mathrm{C})$ or from tumoral tissue $(\mathrm{RG} 2)$ were incubated with DMEM plus $2 \mu \mathrm{Ci} / \mathrm{ml}^{3} \mathrm{H}$-methyl-tymidine alone $(\mathrm{C}, \mathrm{RG} 2)$ or $\mathrm{DMEM}+2 \mu \mathrm{Ci} / \mathrm{ml}$ [methyl- $\left.{ }^{3} \mathrm{H}\right]$-thymidine $+50(\mathrm{C}+\mathrm{G} 50, \mathrm{RG} 2+\mathrm{G} 50) \mu \mathrm{M}$ genistein for $90 \mathrm{~min}$. Data are the mean $\pm \mathrm{SD}$ of one (of two) representative experiment performed by quadruplicate.

containing $2 \mu \mathrm{Ci} / \mathrm{ml}$ [methyl- $\left.{ }^{3} \mathrm{H}\right]$-thymidine +0 or $50 \mu \mathrm{M}$ genistein. As control, tissue mini-units obtained from normal cerebral cortex of the opposite hemisphere of the same animal was used. Fig. 5 shows the percentage of DNA synthesis inhibition induced by $50 \mu \mathrm{M}$ genistein in glioma cells as well as in adult rat cerebral cortex. The result show that the incorporation of [methyl- ${ }^{3} \mathrm{H}$-thymidine in glioma cells is very high when compared to normal rat cerebral cortex and that $50 \mu \mathrm{M}$ genistein produced a strong inhibitory effect in glioma cells with no significant effect on normal tissue probably due to the low proliferative acivity of the adult normal brain tissue.

\section{Discussion}

To the best of our knowledge, this is the first report on the effect of genistein on ongoing DNA synthesis rate in tissue specimen from human gliomas and from the rat RG2 glioma model. More than $50 \%$ inhibition of DNA synthesis rate by $100 \mu \mathrm{M}$ genistein was observed in $12 / 21$ of the tumor specimens (Table I). The inhibitory effect was shown to be concentration-dependent (Fig. 3) and of short-time onset (Fig. 4) as previously reported for normal rat cerebral cortex (11). Genistein increased the DNA synthesis rate in 3 cases. Although this enhancement is in contrast with the results for the major part of tumor specimens and the existing literature, an enhancement of experimental colon cancer by dietary genistein was reported by Rao et al (17). The authors emphasize that the biological effects of genistein may be organ specific and inhibit cancer development in some sites while showing no effect or an enhancing effect on the tumorigenesis at other sites. Our results suggest that the effect of genistein may also show interindividual variation even for tumors of the same histopathological type.

The tumors included in this study showed a considerable intertumoral variation in the spontaneous DNA synthesis rate 
(Table I). This variation is unlikely to be due to a lack of reproducibility of the mini-unit method since i) the temporal course for [methyl- ${ }^{3} \mathrm{H}$ ]-thymidine incorporation into DNA was found to be linear up to 90 min despite a strong variation in the net radioactive incorporation into DNA (Fig. 1), ii) in a previous study, a similar intertumoral variation of spontaneous DNA synthesis rate has been found while the effect of another drug (roscovitine) on ongoing DNA synthesis was highly reproducible in mini-units prepared from human gliomas (13) and human cervical cancer (18), and iii) a high reproducibility of DNA synthesis rate determinations has been observed for mini-units prepared from normal rat cerebral cortex $(11,15)$. In addition, other methods for measuring cell proliferation rate with preservation of the in situ metabolism and topology show a discrepancy between cell proliferation rate and cellular histopathology, e.g., the great variation in PCNA labeling index in glioblastomas (19) and the equivalent $\mathrm{Ki}-67$ reactivity in tumors with significant malignancy grade differences (20).

Genistein could decrease the DNA synthesis rate of human glioma cells by i) a short-time onset mechanism of action as reported here, and ii) a long-time onset mechanism of action probably due to inhibition of the EGF-R associated tyrosine kinase activity and/or inhibiton of tyrosine phosphorylation of proteins important for signal transduction $(8,12)$. We suggest that the early inhibition of glioma DNA synthesis rate by genistein observed in this study is independent of protein phosphorylation and probably due to inhibition of topoisomerase II activity: i) The short-time onset (within $30 \mathrm{~min}$ ) of the inhibitory effect on DNA synthesis observed in this study was also found for normal rat cerebral cortex where the effect was found to be mediated by topoisomerase II inhibition $(11,15)$. ii) More important, herbimycin A, a potent tyrosine kinase inhibitor, had no effect on DNA synthesis rate while the selective topoisomerase II inhibitor etoposide, inhibited similarly to that of genistein. iii) Ongoing DNA replication in normal rat cerebral cortex is relatively independent of protein kinase inhibition (15). iv) If the genistein effect was mediated through inhibition of protein phosphorylation related to mitogenic signalling pathways, a considerable lag would be expected until the fall in DNA synthesis rate (15). Consistent with this assumption, the inhibitory effect of genistein on ongoing DNA synthesis in mini-units prepared from rat cerebral cortex was not reversed by sodium orthovanadate, a potent inhibitor of phosphotyrosine phosphatases (15). Recent literature data support a topoisomerase II dependent mechanism in the arrest and induction of apoptosis in 4 different gliomas cell lines $(21)$ at a concentration range used in our study $\left(\mathrm{EC}_{50}\right.$ concentrations of 20-80 $\mu \mathrm{M}$ ).

It has been suggested that genistein or other isoflavones are related to the lower incidence of breast and prostate cancer in Asians with a high intake of soy products (22). Furthermore, it has been shown that genistein at $75-150 \mathrm{mg} /$ $\mathrm{kg}$ /day reduces the formation of premalignant conditions in the colon of rats exposed to azoxymethane (23).

Although genistein at high doses may be toxic for rapidly proliferating normal neural cells (newborn rats), and adverse effect have been reported when genistein was administered during neonatal treatments (24) the toxicity seems to be less in cells derived from slowly proliferating tissue such as adult rat cerebral cortex (11). Genistein can be given in vivo with tolerable toxicity (12). Moreover, recent data indicate that genistein at pharmacological doses does not give any reproductive or developmental alterations even after chronic treatments (25-27). Asians consuming a traditional diet with high soy product content may show high plasma concentrations (up to $2.4 \mu \mathrm{M}$ ) of genistein (28). This concentration is close to the $\operatorname{IC}_{50}(2.7 \mu \mathrm{M})$ for the autophosphorylation of the EGF-R associated tyrosine kinase and the $\operatorname{IC}_{50}(5 \mu \mathrm{M})$ for topoisomerase II (6). In male Wistar rats, the plasma level of total genistein after an oral dose of $2,000 \mathrm{mg} / \mathrm{kg}$ was maintained at levels of $\sim 40 \mu \mathrm{M}$ for around $9 \mathrm{~h}$. Even at these high levels no genotoxic effect was observed using different mutagenic and clastogenic tests (29). In a human prostate cell line genistein inhibits cell proliferation only at high concentration (50-100 $\mu \mathrm{M})(30)$. New delivery methods of drugs such as intracerebroventricular injection $(31,32)$, might allow the application of high concentration of genistein into the brain while preserving potential systemic toxicity in other high proliferating tissue. Considering the fact that the median survival time is 9-14 months in patients with high malignancygrade gliomas (33), our results encourage further studies in order to investigate the chemotherapeutic and chemopreventive potential of genistein for these tumors.

\section{Acknowledgements}

This study was supported by grants from the Karolinska Institute, the Minerva Foundation, the Swedish Medical Association and the Swedish Research Council. The access to resources at the Clinical Research Center, Novum, is gratefully acknowledged. We thank Dr Lars Wallstedt for providing the last seven tumor specimens and Britt Mejer for helping with the RG2 glioma model.

\section{References}

1. Oude Weernink PA, Verheul E, Kerkhof E, van Veelen CWM and Rijksen G: Inhibitors of protein tyrosine phosphorylation reduce the proliferation of two glioma cell lines. Neurosurgery 38: 108-114, 1996.

2. Penar PL, Khoshyomn S, Bhushan A and Tritton TR: Inhibition of epidermal growth factor receptor-associated tyrosine kinase blocks glioblastoma invasion of the brain. Neurosurgery 40: 141-151, 1997.

3. Ekstrand AJ, James CD, Cavenne WK, Seliger B, Pettersson RF and Collins VP: Genes for epidermal growth factor receptor, transforming growth factor $\alpha$, and epidermal growth factor and their expression in human gliomas in vivo. Cancer Res 51: 2164-2172, 1991.

4. Barnes S: Effects of genistein on in vitro and in vivo models of cancer. J Nutr 125: S777-S783, 1995.

5. Khoshyomn S, Nathan D, Manske GC, Osler TM and Penar PL: Synergistic effect of genistein and BCNU on growth inhibition and cytotoxicity of glioblastoma cells. J Neurooncol 57: 193-200, 2002.

6. Markovits J, Linassier C, Fosse P, et al: Inhibitory effects of the tyrosine kinase inhibitor genistein on mammalian DNA topoisomerase II. Cancer Res 49: 5111-5117, 1989.

7. Motojima K and Goto S: Histidyl phosphorylation and dephosphorylation of P36 in rat liver extract. J Biol Chem 269: 9030-9037, 1994.

8. Kim H, Peterson G and Barnes S: Mechanisms of action of the soy isoflavone genistein: emerging role for its effects via transforming growth factor B-signaling pathways. Am J Clin Nutr 68 (Suppl.): S1418-S1425, 1998. 
9. Bandele OJ and Osheroff N: The efficacy of topoisomerase IItargeted anticancer agents reflects the persistence of drug-induced cleavage complexes in cells. Biochemistry 47: 11900-11908, 2008.

10. Setchell KDR: Phytoestrogens: the biochemistry, physiology, and implications for human health of soy isoflavones. Am J Clin Nutr 68 (Suppl.): S1333-S1346, 1998.

11. Yakisich JS, Sidén A, Idoyaga Vargas V, Eneroth P and Cruz M: Fast and sensitive method for simultaneous measurement of cell proliferation rate and drug sensitivity in rat cerebral cortex. Exp Neurol 151: 194-202, 1998.

12. Clark JW, Santos-Moore A, Stevenson LE and Frackleton R Jr: Effect of tyrosine kinase inhibitors on the proliferation of human breast cancer cell lines and proteins important in the ras signalling pathway. Int J Cancer 65: 186-191, 1996.

13. Yakisich JS, Boethius J, Ohlsson Lindblom I, et al: Inhibition of DNA synthesis in human gliomas by roscovitine. Neuroreport 10: 2563-2567, 1999.

14. Wahlberg LU, Almqvist PM, Glantz MJ and Boethius J: Polymeric controlled-release amsacrine chemotherapy in an experimental glioma model. Acta Neurochir (Wien) 138: 1323-1330, 1996.

15. Yakisich JS, Sidén Å, Idoyaga Vargas V, Eneroth P and Cruz M: Early effect of protein kinase modulators on DNA synthesis in rat cerebral cortex. Exp Neurol 159: 164-176, 1999.

16. Uehara $\mathrm{Y}$ and Fukazawa H: Use and selectivity of Herbymicyn A as inhibitor of protein-tyrosine kinase. Methods Enzymol 201: 370-379, 1991.

17. Rao CV, Wang C-X, Simi B, et al: Enhancement of experimental colon cancer by genistein. Cancer Res 57: 3717-3722, 1997.

18. Vitali L, Yakisich JS, Vita MF, et al: Roscovitine inhibits ongoing DNA synthesis in human cervical cancer. Cancer Lett 180: 7-12, 2002 .

19. Revesz T, Alsanjari N, Darling JL, Scaravilli F, Lane DP and Thomas DG: Proliferating cell nuclear antigen (PCNA): expression in samples of human astrocytic gliomas. Neuropathol Appl Neurobiol 19: 152-158, 1993.

20. Garcia R, Bueno A, Castanon S, et al: Study of the DNA content by flow cytometry and proliferation in 281 brain tumors. Oncology 54: 112-117, 1997.

21. Schmidt F, Knobbe CB, Frank B, Wolburg H and Weller M: The topoisomerase II inhibitor, genistein, induces G2/M arrest and apoptosis in human malignant glioma cell lines. Oncol Rep 19: 1061-1066, 2008.
22. Peterson G: Evaluation of the biochemical targets of genistein in tumor cells. J Nutr 125: S784-S789, 1995.

23. Steele VE, Pereira MA, Sigman CC and Kellof GJ: Cancer chemoprevention agent development strategies for genistein. J Nutr 125: S713-S716, 1995.

24. Jefferson WN, Padilla-Banks E and Newbold RR: Adverse effects on female development and reproduction in $\mathrm{CD}-1$ mice following neonatal exposure to the phytoestrogen genistein at environmentally relevant doses. Biol Reprod 73: 798-806, 2005.

25. Lamartiniere CA, Zhang J-X and Cotroneo MS: Genistein studies in rats: potential for breast cancer prevention and reproductive and developmental toxicity. Am J Clin Nutr 68 (Suppl.): S1400-S1405, 1998.

26. Eason RR, Till SR, Velarde MC, et al: Uterine phenotype of young adult rats exposed to dietary soy or genistein during development. J Nutr Biochem 16: 625-632, 2005.

27. McClain RM, Wolz E, Davidovich A, Pfannkuch F, Edwards JA and Bausch J: Acute, subchronic and chronic safety studies with genistein in rats. Food Chem Toxicol 41: 56-80, 2005.

28. Adlercreutz H, Markkanen $\mathrm{H}$ and Watanabe S: Plasma concentrations of phyto-oestrogens in japanese men. Lancet 342: 1209-1210, 1993.

29. McClain RM, Wolz E, Davidovich A and Bausch J: Genetic toxicity studies with genistein. Food Chem Toxicol 44: 42-55, 2005.

30. Wang X, Clubbs EA and Bomser JA: Genistein modulates prostate epithelial cell proliferation via estrogen- and extracellular signal-regulated kinase-dependent pathways. J Nutr Biochem (In press).

31. Osuga H, Osuga S, Wang F, et al: Cyclin-dependent kinases as a therapeutic target for stroke. Proc Natl Acad Sci USA 97: 10254-10259, 2000.

32. Zhang M, Li J, Chakrabarty P, Bu B and Vincent I: Cyclindependent kinase inhibitors attenuate protein hyperphosphorylation, cytoskeletal lesion formation, and motor defects in Niemann-Pick Type C mice. Am J Pathol 165: 843-853, 2004.

33. Barker FG II, Chang SM, Gutin PH, et al: Survival and functional status after resection of recurrent glioblastoma multiforme. Neurosurgery 42: 709-723, 1998. 